\title{
Randomised double-blind trial of acyclovir and idoxuridine in dendritic corneal ulceration
}

\author{
L. M. T. COLLUM, ${ }^{1}$ A. BENEDICT-SMITH, ${ }^{1}$ AND I. B. HILLARY ${ }^{2}$ \\ From the ${ }^{1}$ Royal Victoria Eye and Ear Hospital and Research Foundation, Eye and Ear \\ Hospital, Dublin, and the ${ }^{2}$ Department of Medical Microbiology, University College, Dublin
}

SUMmary The results of a randomised double-blind clinical trial of $3 \%$ acyclovir and $0.5 \%$ idoxuridine (IDU) ophthalmic ointments in 60 patients with corneal dendritic ulceration are presented. Ulcers in all 30 patients treated with acyclovir healed compared with $22(76 \%)$ of 29 patients treated with IDU $(\mathrm{P}<0 \cdot 01)$. Patients treated with acyclovir healed more rapidly (average 4.4 days) than those who received IDU (average 9.2 days) $(\mathrm{P}<0.01)$. No serious side effects were observed, though transient stinging was recorded in 8 patients receiving acyclovir and in 2 patients receiving IDU. Other side effects in the IDU treated group were watering in 2 patients and superficial punctate erosions in 6 patients.

Idoxuridine (IDU) has been used for the treatment of herpes simplex keratitis since 1962, ${ }^{1}$ and its efficacy in treating this infection has been established. Results from controlled trials indicate an average cure rate of $76 \% \cdot{ }^{2-10}$ However, the drug is known to produce toxic effects, including follicular conjunctivitis, contact dermatitis, epithelial keratitis, and occlusion of the punctum. ${ }^{11}$ More effective and less toxic alternatives have been sought. Adenine arabinoside (ara-A) has a similar level of efficacy to IDU, ${ }^{6}$ while trifluorothymidine (F3TDR) is somewhat more effective. ${ }^{12}$

Acyclovir (Zovirax, 9-(2-hydroxyethoxymethyl)guanine) was developed by Elion, Schaeffer, and Bauer. ${ }^{13}{ }^{14}$ In vitro acyclovir is over 10 times more active against herpes simplex virus (HSV) type I than either IDU or F3TDR. The first step in the phosphorylation of acyclovir to the active triphosphate is carried out by viral specified thymidine kinase. Acyclovir triphosphate inhibits HSV DNA polymerase 10-30 times more effectively than cellular DNA polymerase, resulting in preferential inhibition of viral DNA synthesis.

Acyclovir has been shown to be superior to IDU in the treatment of experimental corneal infections with HSV in the rabbit ${ }^{15}$ and has also shown promise in treating dendritic ulceration in man. In patients treated with minimal wipe debridement Jones et al. ${ }^{16}$ showed that topical treatment with acyclovir prevented early recurrences in comparison with placebo.

Correspondence to $\mathrm{Mr}$ L. M. T. Collum, 9 Fitzwilliam Place, Dublin 2.
Recently acyclovir was shown to be effective without debridement in treating a series of patients with dendritic ulceration, a proportion of whom had failed to respond to other antiviral agents. ${ }^{17}$ This report describes the results of a randomised double-blind controlled trial of acyclovir and IDU ophthalmic ointments in patients with superficial corneal ulceration.

\section{Materials and methods}

Sixty patients were included in the study. Informed consent to participation in the investigation was obtained from patients or parents as appropriate. Uniocular patients and those who had received local antiviral treatment or steroids during the preceding 2 months were excluded. Diagnosis was based on clinical criteria; full ocular examinations were carried out initially and during the follow-up assessments. Patients were examined as often as clinically necessary, but all were seen at least twice weekly. Conjunctival swabs were taken for virus culture, and sera were collected for titration of complement fixing (CF) antibodies to herpes simplex virus (HSV). Treatment 5 times daily with either $3 \%$ acyclovir or $0.5 \%$ IDU ophthalmic ointments was randomly allocated. The ointments were of similar appearance and packed in identical tubes. In addition all patients received $1 \%$ homatropine eye drops twice daily and the infected eyes were padded. If no improvement had occurred after 4 days' treatment, the patient was withdrawn from the study and treated with $3 \%$ ara-A ophthalmic oint- 
ment. Ulcers were considered to have healed when there was no fluorescein uptake, and the day of healing was noted. Symptoms of pain, photophobia, lachrymation, and grittiness were scored at each visit on a four point scale ( 0 -absent, $1-$ mild, 2-moderate, 3-severe).

\section{VIROLOGY}

Conjunctival swabs were placed in virus transport medium immediately after collection. As soon as possible thereafter $0.2 \mathrm{ml}$ of the transport medium was incculated into available cell cultures. The cultures in routine use were Vero, HeLa, primary African green monkey kidney, and human embryo lung (HEL) fibroblasts. Specimens were considered positive if they produced cytopathic effects (CPE) in HEL fibroblasts and one or more of the other cell cultures, and negative if they failed to produce CPE in HEL fibroblasts and at least 2 other cell types. Virus isolates were identified by neutralisation with antisera supplied by the standards laboratory for Serological Reagents, Public Health Laboratory Service, Colindale. Sera were titrated for CF antibody to HSV type I by standard methods.

\section{Results}

Thirty patients were entered into each group; 1 patient in the IDU treated group failed to attend

Table 1 Comparison of acyclovir and IDU treated groups at presentation

\begin{tabular}{|c|c|c|}
\hline & Acy lovir & $I D U$ \\
\hline \multicolumn{3}{|l|}{ Number of patients } \\
\hline Number $(\%)$ female & $11(36.7 \%)$ & $5(16 \cdot 7 \%)$ \\
\hline Age range $(y r)$ & 4-79 & $18-62$ \\
\hline Average age $(\mathrm{yr})$ & 39 & 43 \\
\hline \multicolumn{3}{|c|}{ Duration of sy:nptoms before treatment } \\
\hline$<2$ weeks & 22 patients & 24 patients \\
\hline $2-4$ weeks & 8 patients & 3 patients \\
\hline$>4$ wceks & 0 patients & 3 patients \\
\hline \multicolumn{3}{|c|}{$\begin{array}{l}\text { Average severity of symptoms at presentation } \\
\text { (range } 0-3)\end{array}$} \\
\hline Pain & $1 \cdot 6$ & $1 \cdot 5$ \\
\hline Photophobia & $1 \cdot 3$ & $1 \cdot 7$ \\
\hline Lachrymation & $1 \cdot 5$ & 1.9 \\
\hline Grittiness & $1 \cdot 4$ & $1 \cdot 4$ \\
\hline \multicolumn{3}{|c|}{ Approximate ulcer size at presentation } \\
\hline Range & $1-36 \mathrm{~mm}^{2}$ & $1-49 \mathrm{~mm}^{2}$ \\
\hline Average & $8.3 \mathrm{~mm}^{2}$ & $8.3 \mathrm{~mm}^{2}$ \\
\hline $\begin{array}{l}\text { Number of patients } \\
\text { with uveitis }\end{array}$ & 5 & $3 \dagger$ \\
\hline
\end{tabular}

*One patient failed to attend for follow-up. †Two additional patients developed uveitis during treatment. for follow-up. The 2 groups of patients were similar with regard to sex and age distributions, duration and severity of symptoms before treatment, occurrence of uveitis, and size of corneal ulcers (Table 1). Herpes simplex virus type I was rezovered from $19(33 \%)$ of 54 conjunctival swabs. CF antibody to HSV type I was present in $48(96 \%)$ of sera. There were no differences in the rate of recovery of HSV or in the percentage of patients with $\mathrm{CF}$ antibody tetween the 2 groups.

All ulcers treated with acyclovir healed, while ulcers in $7(24.1 \%)$ of 29 patients were not improved or had become worse after 4 days' treatment with IDU ( $P<0.01$, Cox's logit procedure). These patients were withdrawn from the study. The number of days taken to heal in patients treated with acyclovir ranged from 2 to 9 days (average 4.4 days), compared with 3 to 17 days (average $9 \cdot 2$ days) for patients treated with IDU (Tables 2 and 3 ).

Table 2 Thirty patients treated with acyclovir

\begin{tabular}{|c|c|c|c|c|c|}
\hline $\begin{array}{l}\text { Patient } \\
\text { sex, } \\
\text { age } \\
(y r)\end{array}$ & $\begin{array}{l}\text { Number } \\
\text { of days } \\
\text { to } \\
\text { healing }\end{array}$ & Side effects & $\begin{array}{l}\text { Recovery } \\
\text { of HSV } \\
\text { from con- } \\
\text { junctival } \\
\text { swabs }\end{array}$ & $\begin{array}{l}\text { Titre of } \\
\text { complement } \\
\text { fixing } \\
\text { antibody } \\
\text { to HSV }\end{array}$ & $\begin{array}{l}\text { Fcllow- } \\
\text { up } \\
\text { period } \\
\text { (months) }\end{array}$ \\
\hline M48 & 4 & Nil & - & $1 / 16$ & 13 \\
\hline M58 & 4 & Nil & - & $1 / 64$ & 13 \\
\hline M12 & 4 & Nil & + & $1 / 256$ & 13 \\
\hline M53 & 4 & Nil & - & $1 / 32$ & 13 \\
\hline F54 & 3 & Stinging & - & $1 / 32$ & 12 \\
\hline M70 & 4 & Sore tongue & - & $1 / 32$ & 12 \\
\hline M40 & 3 & Nil & - & $1 / 32$ & 12 \\
\hline F58 & 5 & Nil & + & $1 / 16$ & 11 \\
\hline M55 & 6 & $\mathrm{Nil}$ & - & $1 / 16$ & 11 \\
\hline F4 & 9 & Stinging & + & ND & 10 \\
\hline M37 & 4 & Nil & + & $1 / 16$ & 10 \\
\hline M62 & 3 & Stinging & - & $1 / 8$ & 10 \\
\hline M35 & 4 & Nil & + & $1 / 32$ & 10 \\
\hline F22 & 4 & Nil & + & $1 / 16$ & 10 \\
\hline F22 & 4 & Stinging & + & $1 / 16$ & 9 \\
\hline M79 & 5 & Nil & + & $1 / 32$ & 9 \\
\hline F11 & 7 & Nil & ND & ND & 8 \\
\hline M23 & 6 & Nil & $t$ & ND & 8 \\
\hline$F 12$ & 4 & Stinging & - & $1 / 64$ & 8 \\
\hline F73 & 5 & Stinging & - & $1 / 32$ & 8 \\
\hline M41 & 5 & Nil & - & $1 / 32$ & 7 \\
\hline F12 & 2 & Nil & - & $1 / 32$ & 7 \\
\hline M57 & 3 & Stinging & - & $1 / 32$ & 6 \\
\hline M25 & 4 & $\mathrm{Nil}$ & - & $1 / 32$ & 6 \\
\hline F26 & 5 & Nil & ND & ND & 5 \\
\hline M42 & 4 & Nil & - & $1 / 32$ & 4 \\
\hline M8 & 4 & Nil & - & ND & 4 \\
\hline M52 & $3^{*}$ & $\mathrm{Nil}$ & - & $1 / 32$ & 4 \\
\hline M49 & 3 & $\mathrm{Nil}$ & - & $1 / 32$ & 4 \\
\hline F26 & 6 & Stinging & - & $1 / 32$ & $2 !$ \\
\hline
\end{tabular}

ND $=$ Not done. *Recurred after 3 weeks. 
Table 3 Thirty patients treated with IDU

\begin{tabular}{|c|c|c|c|c|c|}
\hline $\begin{array}{l}\text { Patient } \\
\text { sex, } \\
\text { age } \\
(y r)\end{array}$ & $\begin{array}{l}\text { Number of } \\
\text { days to } \\
\text { healing }\end{array}$ & $\begin{array}{l}\text { Side } \\
\text { effects }\end{array}$ & $\begin{array}{l}\text { Recovery } \\
\text { of } \mathrm{HSV} \\
\text { from con- } \\
\text { junctival } \\
\text { swabs }\end{array}$ & $\begin{array}{l}\text { Titre of } \\
\text { complement } \\
\text { fixing } \\
\text { antibody } \\
\text { to HSV }\end{array}$ & $\begin{array}{l}\text { Follow- } \\
\text { up } \\
\text { period } \\
\text { (months) }\end{array}$ \\
\hline M51 & 7 & Nil & - & $1 / 32$ & 13 \\
\hline M55 & 8 & SPE & - & $1 / 32$ & 13 \\
\hline M52 & 10 & Nil & 一 & $1 / 32$ & 13 \\
\hline M50 & 9 & SPE & ND & ND & 12 \\
\hline M34 & Withdrawn & - & + & $1 / 64$ & - \\
\hline M61 & 8 & Nil & + & $1 / 32$ & 11 \\
\hline F47 & Withdrawn & - & ND & ND & - \\
\hline F41 & $10^{*}$ & Irritation & - & $1 / 64$ & 11 \\
\hline M60 & Defaulted & - & 一 & $1 / 32$ & - \\
\hline M40 & 11 & Nil & + & $1 / 32$ & 11 \\
\hline M34 & 7 & Nil & - & $1 / 16$ & 10 \\
\hline M25 & 10 & SPE & - & $1 / 64$ & 10 \\
\hline M40 & 7 & SPE & + & $1 / 32$ & 10 \\
\hline M35 & $8 \dagger$ & Stinging & - & $1 / 8$ & 10 \\
\hline M60 & 8 & Nil & - & $1 / 16$ & 10 \\
\hline M40 & 8 & Nil & - & $1 / 16$ & 10 \\
\hline M18 & 8 & Nil & 一 & $1 / 16$ & 9 \\
\hline F49 & 8 & Nil & + & $1 / 32$ & 9 \\
\hline M49 & Withdrawn & - & ND & ND & - \\
\hline M24 & Withdrawn & - & - & $1 / 8$ & - \\
\hline F50 & 10 & Nil & + & $1 / 32$ & 7 \\
\hline F62 & Withdrawn & - & ND & ND & - \\
\hline M40 & 11 & Nil & - & $1 / 32$ & 6 \\
\hline M40 & Withdrawn & - & 4 & $1 / 32$ & - \\
\hline M48 & 17 & SPE & + & $1 / 32$ & 6 \\
\hline M23 & 3 & SPE & - & $1 / 32$ & 4 \\
\hline M27 & 7 & Watering & - & $1 / 32$ & 4 \\
\hline M56 & Withdrawn & - & + & $1 / 8$ & - \\
\hline M22 & 10 & Watering & + & $1 / 64$ & 3 \\
\hline M58 & 6 & Nil & - & $1 / 64$ & 3 \\
\hline
\end{tabular}

ND $=$ Not done. SPE $=$ Superficial punctate erosion. *Recurred after 8 weeks. †Recurred after 4 months.

The cumulative rate of healing for both treatments is given in Fig. 1. The difference between the 2 groups in terms of healing rate was significant ( $P<\mathbf{0 . 0 1}$, log rank analysis). Two of 30 patients treated with acyclovir and 20 of 29 patients treated with IDU took more than 6 days to heal.

Five patients presented with uveitis in the group treated with acyclovir, which resolved in 3-11 days (average 7 days). Uveitis was present in 3 patients treated with IDU and developed during treatment in a further 2. Two patients were withdrawn from the study, while the other 3 resolved, respectively in 2,7 , and 23 days.

Symptoms of pain, photophobia, lachrymation, and grittiness resolved within 11 days in all except 4 patients-all of whom were treated with IDU.

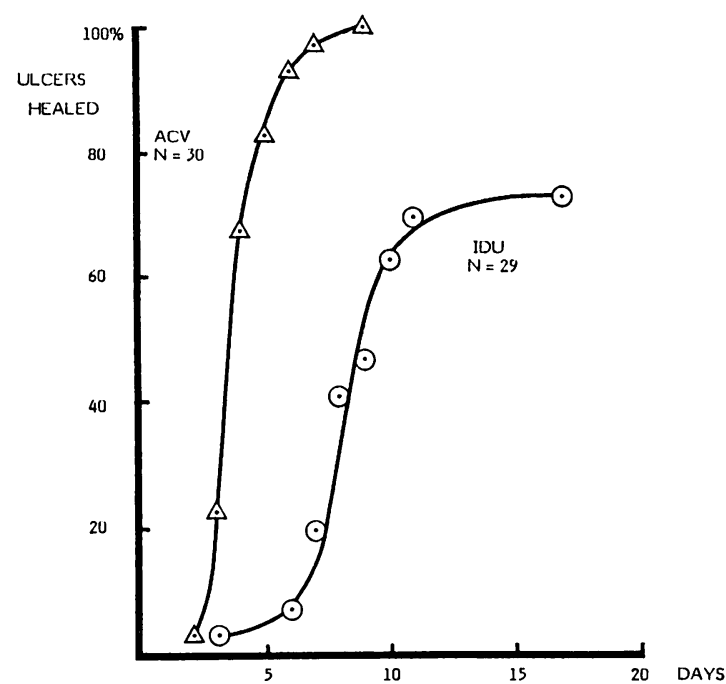

Fig. 1 Cumulative frequency distribution of time to heal dendritic corneal ulcers. $A C V=$ acyclovir. IDU $=$ idoxuridine.

For each symptom, resolution was more rapid after treatment with acyclovir (Table 4).

Stinging on initial application of the ointment was noted by 8 patients treated with acyclovir and by 2 patients treated with IDU. One patient treated with acyclovir complained of a sore tongue. Watering of the eye was experienced by a further 2 patients treated with IDU. This necessitated dilatation of the puncta and syringing of the duct in 1 patient. Superficial punctate epitheliopathy was noted in 6 other patients treated with IDU. Summaries of side effects for both treatment groups are given in Tables 2 and 3.

Patients in both groups have been followed up for 2.5-13 months (average 8.7 months acyclovir, 8.9 months IDU). One recurrence occurred 3 weeks after treatment with acyclovir, and 2 patients had recurrences after treatment with IDU, at 8 weeks and 4 months respectively.

Table 4 Resolution of symptoms in patients receiving acyclovir and IDU

\begin{tabular}{llc}
\hline \multirow{2}{*}{ Symptom } & \multicolumn{2}{l}{ Number of days to resolve } \\
\cline { 2 - 3 } & Acyclovir & $I D U$ \\
\hline Pain & 7.0 & $8 \cdot 0$ \\
Photophobia & 8.4 & $11 \cdot 2^{*}$ \\
Lachrymation & 8.8 & $11 \cdot 0 \dagger$ \\
Grittiness & 7.6 & $9 \cdot 0^{*}$ \\
\hline
\end{tabular}

*One patient failed to resolve during treatment. †Three patients failed to resolve during treatment. 


\section{Discussion}

Acyclovir was found to be superior to IDU in the treatment of superficial dendritic ulceration of the cornea, healing a larger proportion of ulcers at a more rapid rate. The proportion of IDU treated ulcers which failed to respond to treatment is similar to the average reported in previous trials. Significant side effects were not observed with acyclovir, but some patients complained of transient stinging on instillation of the ointment. No epitheliopathy was observed even in 3 patients in whom treatment was given for 20 days. Residual corneal scarring seemed to be less in the patients treated with acyclovir. This may be related to the shorter healing time in comparison with those treated with IDU.

Further studies of acyclovir are needed in patients with deeper HSV infections of the eye. Clearly the effects of topically administered acyclovir should be evaluated first. However, the drug has been administered intravenously in immunosuppressed patients with severe local and disseminated HSV infections with apparent benefit and without significant side effects, ${ }^{18} 19$ and combined topical and systemic administration may be an approach for the future.

We thank our colleagues who kindly allowed access to their patients, Dr W. D. Brigden and Mr T. Ravenscroft, Wellcome Research Laboratories, Beckenham, for coded supplies of acyclovir and IDU, and Mr P. Smith for the statistical analyses.

\section{References}

1 Kaufman HE, Martola EL, Dohlman CH. Use of IDU in treatment of herpes simplex keratitis. Arch Ophthalmol 1962; 68: 235-9.

2 Burns RP. A double-blind study of IDU in human herpes simplex keratitis. Arch Ophthalmol 1963; 78: 381-4

3 Patterson A, Fox AD, Davies G, et al. Controlled studies of IDU in the treatment of herpetic keratitis. Trans Ophthalmol Soc UK 1963; 83: 583-91.

4 Laibson PR, Leopold IH. An evaluation of double-blind
IDU therapy in 100 cases of herpetic ,keratitis. Trans Am Acad Ophthalmol Otolaryngol 1964; 68: 22-34.

5 Hart DRL, Brightman VJF, Readshaw GG, Porter GTJ, Tully MJ. Treatment of human herpes simplex keratitis with idoxuridine. Arch Ophthalmol 1965; 73: 623-34.

6 Pavan-Langston D, Dohlman $\mathrm{CH}$. A double-blind clinical study of adenine arabinoside therapy of viral keratoconjunctivitis. Am J Ophthalmol 1972; 74: 81-8.

7 Hyndiuk RA, Schultz RO, Hull DS. Herpetic keratitisclinical evaluation of adenine arabinoside and idoxuridine. In: Pavan-Langston D, Buchanan RA, Alford CA, eds. Adenine Arabinoside: An Antiviral Agent. New York: Raven Press, 1975; 331-5.

8 Blake J, Brown M. Treatment of herpetic keratitis. Doc Ophthalmol 1977; 44: 23-33.

9 Markham RHC, Carter C, Scobie MA, Metcalf C, Easty DL. Double-blind trial of adenine arabinoside and idoxuridine in herpetic corneal ulcers. Trans Ophthalmol Soc UK 1977; 97: 333-40.

10 Chin GN. Treatment of herpes simplex with idoxuridine and vidarabine: a double-blind study. Ann Ophthalmol $1978 ; 10$ : $1171-4$.

11 Patterson A, Jones BR. The management of ocular herpes. Trans Ophthalmol Soc UK 1967; 87: 59-84.

12 Wellings PC, Awdry PN, Bors FH, Jones BR, Brown DC, Kaufman HE. Clinical evaluation of trifluorothymidine in the treatment of herpes simplex corneal ulcers. Am J Ophthalmol 1972; 73: 932-42.

13 Elion GB, Furman PA, Fyfe JA, de Miranda P, Beauchamp L, and Schaeffer HJ. Selectivity of action of an antiherpetic agent, 9-(2-hydroxyethoxymethyl)-guanine. Proc Natl Acad Sci USA 1977; 74: 5716-20.

14 Schaeffer HJ, Beauchamp L, de Miranda P, Elion GB. 9-(2-hydroxyethoxymethyl)guanine activity against viruses of the herpes group. Nature 1978; 272: 583-5.

15 Pavan-Langston D, Campbell R, Lass J. Acyclic antimetabolite therapy of experimental herpes simplex keratitis. Am J Ophthalmol 1978; 86: 618-23.

16 Jones BR, Coster DJ, Fison PN, Thompson GM, Cobo LM, Falcon MG. Efficacy of acycloguanosine (Wellcome 248U) against herpes simplex corneal ulcers. Lancet 1979; i: $243-4$

17 Collum LMT, Benedict-Smith A. Acyclovir in herpetic keratitis. International Symposium on Herpetic Ocular Diseases. Freiburg im Breisgau: Deutsche Ophthalmologische Gesellschaft, 1980 (in press).

18 O'Meara A, Deasy PF, Hillary IB, Brigden WD. Acyclovir for treatment of mucocutaneous herpes infection in a child with leukaemia. Lancet 1979; ii: 1196.

19 Selby PJ, Powles RL, Jameson B, et al. Parenteral acyclovir therapy for herpes virus infections in man. Lancet 1979; ii: 1267-70. 